\title{
Benefits and Pitfalls of Online Grocery Shopping as Perceived by the Consumers: Evidence from the Czech Republic
}

\section{Abstract}

Over the last decade, online grocery shopping has been a growing e-commerce area, currently representing a multi-billion business. While research has been carried out outlining different aspects of consumers' general online shopping behavior, grocery shopping has its specificity in its mundanity and everydayness. As a mundane and routine practice, it affects consumers' everyday lives, as well as other larger-scale issues such as food waste. This paper strives to explore this intersection between online shopping behavior and everyday life. Based on qualitative research, it outlines four behavioral alterations consumers exhibit when switching from offline to online grocery shopping. It then outlines how they fit into and affect their lived experience, creating perceived benefits and/or pitfalls of online grocery shopping.

Keywords: online supermarket, e-commerce, consumer behavior, qualitative research, consumer benefits, Czech Republic

JEL classification: M31, M39

\footnotetext{
* Klára Šarkovská, student, Department of Marketing, Faculty of Business Administration, University of Economics, Prague, Czech Republic, e-mail: klara.sarkovska@gmail.com.

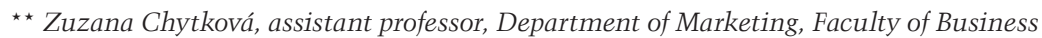
Administration, University of Economics, Prague, Czech Republic, e-mail: zuzana.chytkova@vse.cz.
} 
Over the last decades, e-commerce has been booming and the grocery shopping industry has not been unaffected. An increasing number of grocery chains offer the option to shop for groceries online; moreover, many grocery businesses that operate entirely as an e-commerce platform with no physical stores have been created (Sloot, 2018). According to a research carried out by Morgan Stanley (2016) that surveyed 10,000 consumers in ten countries, groceries might be the next big driver of e-commerce globally. The grocery industry represents a multi-billion dollar business (USD 675 billion in the United States alone in 2016). There is still an enormous potential for growth, as the market share of online groceries remains very low compared to the grocery business overall (around 2 percent in the US and about 6 percent in some European markets such as the UK and France, where online grocery shopping has become somewhat more established). Online grocery shopping is expected to more than double in the next ten years, which would result in nearly 75 percent of consumers buying 25 percent of their groceries online in 2025 (A. C. Nielsen, 2015).

Nevertheless, online grocery shopping is a relatively new trend that has been gaining popularity and practical use on a wider scale only in the last few years (Sloot, 2018) and the depth of existing research is thus still lacking in some areas. Research has mostly focused on the adoption of e-commerce in general (e.g. Mandilas, Karasavvoglou, Nikolaidis, \& Tsourgiannis, 2013; Venkatesh \& Bala, 2008), the situational factors that determine the adoption of online grocery shopping (Chintagunta, Chu, \& Cebollada, 2009), and to a certain extent, the changes in consumer behavior, particularly the impact on product/brand choice in the online supermarket (Degeratu, Rangaswamy, \& Wu, 2000; Shankar, Smith, \& Rangaswamy, 2003; Pozzi, 2009).

What is missing within the existing literature is the consumer's point of view. In other words, the understanding of how switching to online grocery shopping and the shopping behavior changes affect consumers themselves. Based on a qualitative study of online grocery supermarket customers, this 
paper offers an account of four aspects of online grocery shopping that consumers altered after switching to online grocery shopping and that they see as the main benefits and/or pitfalls of this switch. It is outlined how these behavioral alterations affect consumers' everyday lives, particularly the areas of their diet and food waste. This has implications both for research in this area and for online grocery providers, whom it can assist with a better targeting and retention strategy.

\section{Literature Review}

Various aspects of online grocery shopping have been treated in the literature so far. For instance, an extensive amount of research has been undertaken to study the motivations and drivers to adopt shopping for groceries online (e.g. Hand, Riley, Harris, Singh, \& Rettie, 2009; Chintagunta et al., 2009; Pozzi, 2009; Kumar \& Kashyap, 2018; Childers, Carr, Peck, \& Carson, 2001; Jiang, Jiang, \& Liu, 2011). In terms of consumer behavior of online grocery shoppers, it has been shown that online shopping behavior differs notably from offline shopping behavior, not least because online shopping does not involve travel, products cannot be physically inspected at the time of purchase, price uncertainty is decreased by the availability to see the final basket price at any given moment, consumers do not have to carry the product load while shopping, and delivery charges are often involved when shopping online (Chintagunta et al., 2009). It is also more time-efficient compared to offline shopping (Anic \& Radas, 2006).

Within the area of online shopping for groceries, primarily the areas of product search, time efficiency, and product/brand exploration have been researched in the past. Grocery shopping is a utilitarian task and in carrying out this task the consumers look for efficiency and time saving. The online environment offers these benefits, as shown for example by Anesbury, Nenycz-Thiel, Dawes, and Kennedy (2015). In this study, an experiment was conducted with 40 shoppers that had been previously inexperienced with online grocery shopping, asking them to purchase a basket comprising of 12 common grocery categories. The results showed 
that online grocery shopping indeed reflects the consumer's desire for efficiency and time saving during a task seen as utilitarian. The shopping trips were fairly fast for most of the participants regardless of their lack of experience with online grocery shopping.

The time efficiency is closely connected to the fact that most purchases are carried out on the first page of each product category (Anesbury et al., 2015). In other words, consumers consistently use the default option of the page display in the retailer's online store and mostly only view the products displayed on the first page (the default page). This corresponds to other findings, according to which products located on the first page in the retailer's online store yield more purchases (Breugelmans, Campo, \& Gijsbrechts, 2006), although there are numerous ways in which consumers can find a particular item in an online shop.

To find a product in a brick-and-mortar supermarket, a consumer must find the correct aisle and walk down it in order to locate the product. In the online shop, a consumer can use the search function and directly look the product up, view the special offer page directly, or use the "virtual departments" that resemble the aisle organization as if in a traditional supermarket (e.g. dairy, meat, vegetables, fruit). The latter turns out to be the consumers' preferred option. A study, in which 40 participants made an online grocery shopping trip while their eye movement was recorded, revealed that 95 percent of the participants used the "virtual departments" search function, thus copying offline supermarket behavior, 80 percent navigated by searching directly, and 68 percent browsed the special offers (Benn, Webb, Chang, \& Reidy, 2015). Consumers have thus been shown to search for a product in the online environment in a similar way they would search for the same product in a physical supermarket, rather than searching for the product directly. This may be due to the fact that most online grocery retailers simulate a familiar supermarket environment (Anesbury et al., 2015).

Once the consumer finds the relevant product category, s/he is likely to shop on the first page, which corresponds to other findings mentioned 
earlier (Anesbury et al., 2015; Breugelmans et al., 2006). This is also due to the fact that the overload of choice in both traditional and online supermarkets leads to consumers developing a so-called "clutter filter" that screens quickly through the vast selection of brands and products that we find on the shelves or on webpages. Therefore, selecting products quickly, often without browsing, can represent an unconscious protective behavior that consumers use to stay efficient and oblivious to the amount of choice that is presented to them (Sorensen, 2017).

This consumers' quest for efficiency can lead to a lack of brand exploration while shopping for groceries online (Pozzi, 2009). Based on a large dataset of 11,000 consumers who shopped both online and offline, Pozzi (2009) focused on brand exploration within the breakfast cereal category. The results of the research showed that brand exploration is more prevalent in an offline environment than online. Because online grocery shopping tends to be adopted in situations of time shortage, there is a decreased intention to explore unknown brands and products. Moreover, many online grocery providers offer the option to shop based on past shopping history, allowing consumers to buy their favorite products at one click and lessening any intention to browse through virtual aisles and explore new brands. In fact, disabling this feature boosts brand exploration online by 23 percent (Pozzi, 2009). However, brand exploration online is also limited by the impossibility to verify product quality online, resulting in the greater impact of brand name online than offline (Degeratu et al., 2000; Shankar et al., 2003).

As outlined above, there has been a discussion on the consumers' pointof-purchase behavior in the online supermarket and its differences to their offline behavior. In particular, researchers have studied the ways in which consumers find the product and/or brand and how this results in time efficiency. However, what do these different practices mean for consumers' lives? How are they perceived? Once online grocery shopping is adopted as the main provisioning channel for the household's grocery supplies, what strategies do consumers use to maximize the benefits they perceive online shopping can offer and how do these strategies fit into 
and affect their everyday lives? These are the questions this paper aims to address, exploring how changes in shopping behavior, which arise from regular grocery shopping online, are reflected in consumers' everyday lived experience. Knowing how online grocery shopping fits into people's everyday lives allows us to view the effect of e-commerce in the offline world and can help online supermarkets target their consumer segments more efficiently.

\section{Methodology}

The goal of this research was to reveal how online grocery shopping translates into people's everyday lives. As the goal was to understand the changes from the consumer's point of view, qualitative research methods were applied, as they allow us to capture a certain phenomenon using the informant's frame of reference and attempt to experience what the informant is experiencing (Corbin \& Strauss, 2015). In particular, semistructured interviews were conducted with consumers who have had extensive experience with online grocery shopping.

A set of potential topics of interest relevant for the current research was created based on the literature review. These topics were later complemented with exemplary questions that served as guidelines on how to approach the exploration of each of the set topics during the interviews. Both the research topics and interview questions were finalized during the process of data collection.

Following McCracken (1988), the sample consisted of ten online grocery customers. The data sample was chosen in line with the most meaningful characteristics of online grocery customers. First, the selection criteria based on various demographic statistics that describe the typical online grocery shopper in the Czech Republic were identified. These criteria included age, gender, income level, geographical location, and family structure. According to a report from KPMG (2016), 20 percent of the population aged 18 to 44 has shopped online for groceries at least once and another 25 percent is 
planning on trying out online grocery shopping. Based on the same report, which surveyed 1,000 respondents that have the main responsibility for groceries in their households, it is clear that the gender split of grocery shoppers is still large, as 70 percent of all grocery shoppers are female and only 30 percent male. Women are also more experienced online grocery shoppers, with 27 percent shopping for groceries at least once in the past and 11 percent shopping regularly (InsightLab, 2017).

Accordingly, to reflect the structure of online supermarket customers, the informants' age ranged between 23 and 48, and eight customers were female while two were male. The sample includes five respondents who are either working mothers or mothers on maternity leave, and five respondents who are busy professionals. This represents an even split between the two major target groups of online grocery supermarkets: busy professionals and busy parents. Both frequent and infrequent online shoppers were included to cover the diverse roles online grocery shopping can play in consumers' lives. Theoretical saturation in terms of the research question was reached. The list of respondents (with pseudonyms) and their characteristics is included in the Appendix.

The research was conducted during the months of March, April, and May 2018. All interviews were held in the Czech language. Interviews were recorded using a dictation machine. The interview recordings were transcribed verbatim for analysis.

The transcribed data were then analyzed by the hermeneutic process of constant comparison of parts of the interviews to the whole, to the whole dataset, as well as to the literature (Thompson, Locander, \& Pollio, 1989). First, different semantic units (definable sections of the text or interview that carry a certain information; Miovský, 2006) were identified and highlighted within the transcripts. The identified units were later thematically coded by content and grouped by the same code into categories, while comparing the single-coded segments to the whole of the dataset and the literature. 


\section{Research Context}

The Czech Republic is among the top European nations when it comes to the amount of sales of groceries online. Currently 2.5 percent of all sold groceries in the country is sold online, which ranks the Czech Republic 7 th worldwide in the most sold groceries online as a percentage of all sold groceries in the country (Statista, 2015). Online grocery shopping was introduced to the Czech Republic around the beginning of the decade and has since witnessed a booming growth with more sellers entering the market, more regions in which online grocery services are available, and more consumers who have tried to shop or shop regularly for groceries online (GfK Czech Republic, 2017).

As of 2018, more than 50 percent of people in the Czech Republic have tried to place an online order for groceries (compared to 24 percent in 2016) and one out of five customers purchases groceries on the internet regularly (compared to one out of ten in 2016) (InsightLab, 2018). Women are more experienced online grocery shoppers, with 27 percent having shopped for groceries at least once and 11 percent shopping regularly (InsightLab, 2017). Not surprisingly, online purchases are leading among the younger generation and experience with online grocery platforms decreases with age. While 61 percent of people between 18 and 24 have some online grocery experience, the share is 37 percent for the age category above 65 (InsightLab, 2018). The highest number of customers can be found in the Central Bohemia Region and the capital city Prague, while the online grocery platforms are the least used in the rural Liberecky Region and the Kralovehradecky Region. The typical shopper generally comes from a large city that has over 100,000 inhabitants (InsightLab, 2018).

In terms of market share, the market is dominated by three brands, two of which do not possess brick-and-mortar retail spaces: iTesco (an online version of Tesco), Kosik.cz, and Rohlik.cz. Brand recall for these three brands is 66 percent, 62 percent, and 57 percent, respectively. 
Consumers who have adopted online grocery shopping as their main means of buying groceries and/or shop online for groceries on a frequent and regular basis show a substantial change in their shopping behavior in the online supermarket environment when compared to the previous habits in a physical store. In line with the findings of other studies (e.g. Hand et al., 2009; Chintagunta et al., 2009), the consumers switched to regular online shopping either because of an external force driving them out of the traditional store, such as an injury or giving birth, or because of an internal motivation to save time or energy by shopping from the comfort of one's home.

Based on the data, four aspects of online grocery shopping were identified. These factors correspond to the benefits and/or pitfalls of online grocery shopping as perceived by the consumers. In particular, the online grocery shoppers associate online grocery shopping with the following themes, which lead to a perception of particular benefits/pitfalls of online grocery shopping:

1. More efficient shopping planning and perceived higher overall efficiency of shopping trips

2. Increased shopping uniformity and perceived diet monotony

3. Final price awareness throughout shopping and perceived cost efficiency of online grocery shopping

4. Alteration of the range of products bought and perceived benefit of the different product offer

In the following sections, the online supermarket customers' approach to online grocery shopping will be described, as well as the corresponding behavioral pattern in the online supermarket and the consequences of the shopping pattern for the lives of these consumers. 


\subsection{More Efficient Shopping Planning and Perceived Higher Overall Efficiency of Shopping Trips}

As Kumar and Kashyap (2018) postulated, grocery shoppers exhibit utilitarian behavior. Hence, as utilitarian shoppers, they shop on the internet to reach a specific goal most efficiently. Although utilitarian shoppers display similar goal-driven behavior in the traditional brick-andmortar store as well, the convenience of online grocery shopping makes the shopping efficiency even more possible as the utilitarian consumers try to minimize their costs, both financial and non-financial (Kumar \& Kashyap, 2018).

In the current research, the online shopping environment allowed consumers to be more efficient by becoming better planners. Their planning of shopping trips, products to buy, and meals to eat in the following days involved more deliberate planning than when shopping for groceries offline. This can be summarized by Eliška's statement:

"I see the biggest change in the fact that I plan more what we are going to eat. When I used to go to a store, I didn't care too much about it and just bought something on the spot, but now I think more about what we are going to have for meals... Another thing that I feel changed quite a lot for me is that I never used to make shopping lists and then I went to a store and bought for example something that I already had at home and forgot I had it, but that does not happen to me anymore because I just look in the fridge and see if I have it or not... I think [that] my shopping became so much more efficient." (Eliška)

More efficient shopping planning has an immediate effect on the consumers' lives, as they also start to plan the family's diet throughout the week and hence make plans for specific products and ingredients and their quantities. The more rigorous shopping planning that comes with shopping online is documented by some customers only starting to use grocery shopping lists after switching to an online supermarket. The overall better planning of 
meals and shopping lists allowed these customers to reduce the quantity of food that would turn into waste. The quest for efficiency thus has a positive environmental side effect in that it allows for a reduction in food waste. By buying more efficiently, consumers buy less unnecessary products than they used to in the physical supermarket. As Jakub and Eliška put it:

"It rarely happens to me nowadays that something would go bad in my fridge. Before Rohlík [the Czech online supermarket], that was happening quite a lot." (Jakub)

"We throw away much less [food] because I really only buy what we are going to eat and nothing else." (Eliška)

The efficiency of online shopping is clearly associated with time saving. As transpires from the informants' accounts, time efficiency is one of the biggest perceived benefits of using this online service. The aspect of major time saving is particularly appreciated for example by Eliška in the following quote, whose account was almost identical to the accounts of all regular online shoppers:

"When I'm doing an ordinary weekly shopping, when I'm really buying more or less my favorite products from the shopping history and then maybe a few other products, it can easily take me ten minutes. But if I had to go to a normal shop, I have to go by car, I would have to take my little one with me so I would have to dress him and then when we would finally get there, we would spend at least an hour there... so we are comparing maybe an hour and a half to a ten-minute shopping, max 30 minutes when shopping for something special. I really think that once you get used to the app and shopping becomes a routine, it saves you an unbelievable amount of time." (Eliška)

The shopping efficiency was hugely aided by the online supermarket's "favorite" option, which limits the exposure to other products/brands than those usually viewed and bought. This function allows the user to directly 
view his/her favorite and/or previously bought products. We refer to this option as "My Favorites".

\subsection{Increased Shopping Uniformity and Perceived Diet Monotony}

"My Favorites" became one of the most frequently recurring topics during the interviews and explains to a degree the perceived increased efficiency and planning of the online grocery shopping by the informants, who use this page partly as a shopping list. Cecílie, Eliška, and Honza describe the efficiency effect of this function as follows:

"What is really cool [about online supermarkets] is that once you select the items you want for the first time, they will stay there for the future and you can just quickly click on them if you want them again in your next shopping trip. Basically you always buy the same things." (Cecílie)

"What is great about Rohlík [online supermarket] - but other platforms probably have this as well -is that you can use the function that remembers what you are buying and saves the products you have bought last time [as] your favorite products, so I always first go into 'My Favorites' where I click on the usual maybe 15 items I buy all the time such as fruit, bread, cheeses, and so on..." (Eliška)

"[It's] great that you can just have a prepared shopping list [in the 'My Favorites' section] that you buy every Friday again and again and again..." (Honza)

As can be concluded from Honza's statement, the "My Favorites" section can be used as a shopping list itself, thus supplementing the planning process, yet rendering it more efficient. The "My Favorites" function makes it easier for the respondents to shop for products that they are used to. This makes their shopping faster and more efficient as a result. However, consistently with Pozzi (2009), who explored shopping based on past shopping history 
in his research on brand exploration, this feature also lessens the intention to browse through virtual aisles and explore new brands.

Consequently, our informants perceived that their grocery shopping became more uniform than when they shopped in a physical supermarket. This was expressed in a direct acknowledgement and the use of the word "monotonous" in relation to both shopping habits and eating habits. For example, Cecílie feels she is much more "creative" when she goes to a traditional supermarket as she recognizes:

"[We] always just click on our existing list of maybe like 30 things and we always buy the same... We are pretty tight on schedule so we always buy the same... I think that when I go to a normal supermarket, I am much more creative than when I shop online." (Cecílie)

Having the option to buy the same items based on one's shopping history or favorite products creates a shopping routine for the regular online shoppers. Using the "My Favorites" function of the online platform is a way to save time and mental energy. However, the routine becomes so ingrained in their everyday life that it alters the informants' purchasing habits, making their shopping more monotonous. This further leads to a more stereotypical diet and eating habits.

\subsection{Price Awareness and Cost Efficiency}

Although the informants generally see the online supermarket as a premium service with higher prices, they nonetheless feel that online grocery shopping is cost-efficient. Again, this is primarily connected to the perceived efficiency of online shopping, whereas they do not buy unnecessary items which they would buy in a brick-and-mortar store. Hence, the online supermarket environment makes the entire grocery shopping trip on average less costly. As expressed by the informants: 
"I think I save a lot financially as well. When I shop [for groceries] online, I only buy things that I need... but when you go to the supermarket physically, then you can see the products and all the food and you buy things that you don't need... especially when I'm hungry - then I would buy half of the store. That doesn't happen on the internet because you're just not that tempted." (Eliška)

"One doesn't buy that much because you don't see the things physically.” (Cecílie)

"Overall I save money because I don't buy things that I don't need." (Barbora)

In other words, the respondents feel that online shopping represents a financial saving for them because they only buy exactly what they need and are not tempted by the point-of-purchase marketing. This is a significant finding for impulsive product marketing, but also for marketing communication, as consumers in the online environment are apparently more focused on the task and not easily distracted by promotional offers.

However, there is also another process that allows consumers to control the cost of their shopping in the online environment. An online grocery provider operates on the same principle as other e-commerce retailers, automatically saving purchased goods in the shopping cart and automatically calculating the total price of the purchase. This virtual shopping cart is generally visible in the upper right corner of the screen and is present regardless of where the consumer browses on the particular website. It updates automatically when more goods are put in. Hence, a consumer always sees the final price at any given moment.

In the current study, the regular shoppers described that the possibility of seeing the final basket price helps them from going over their personal "price ceiling", as Jakub puts it. Consumers have a clear awareness of the total price that they intend to spend during the shopping trip. The traditional offline supermarket environment, however, does not offer any 
control over this amount. The availability of this control is thus seen as a benefit offered by online grocery shopping. This was exemplified by Barbora, who described the discrepancy of the real cost of her shopping and the cost she had supposed. This, in turn, generates negative feelings about the offline retailer, as when she exclaims: "What am I paying [this money] for?" Elaborating on the topic, she then said:

"When I shop physically, I don't add up all the costs and then I'm surprised at the cashier... but online I can see [the final price] there because it's adding up automatically, so I know straight away if I can add more stuff or not. That's not possible offline." (Barbora)

The shopping cart is used not only as a controlling instrument of the cost itself, but also as a controlling instrument of the shopping cart's contents.

"It's not really only about the money [but] I'm used to buying similar or even the same things every week and then I know exactly that's what I need and that's what I'm going to eat. When I'm above the price ceiling, I know I'm buying useless stuff." (Jakub)

The use of the shopping cart as a control element represents an additional explanation of how the online shoppers achieve overall cost efficiency. This, again, helps reduce the household's food waste.

\subsection{Alteration of the Range of Products Bought}

Although regular online supermarket customers exhibit a very efficient way of shopping for groceries online, rendering their shopping habits automated and their shopping lists quite monotonous, they admit that the range of products they buy altered once they started to shop online. In other words, although they do not tend to experiment with new products and brands after they have switched to the online supermarket and grocery shopping becomes a routine, the different assortment of the online grocery providers introduced new ingredients and products into their diets. Moreover, for 
some respondents, the online grocery assortment was one of the drivers that led them online and hence the different product offering affected them even more substantially.

Ilona exemplifies the story that ran through the accounts of the online shoppers. She started shopping online for groceries more than two years ago because of a knee injury; however, another reason - although less significant at that time - was the range of healthy products that can be found in the online supermarket. Although her knee healed, she never went back to the traditional supermarket shopping and now buys 90 percent of her groceries online. There were many factors that propelled her to stay with the online grocery provider, including time saving and convenience; however, the different product assortment was the main factor that prevented her from going back to the traditional way of grocery shopping. Ilona describes her view on the product offering as follows:

"I got used to buying meat from the farmer's selection on Rohlik, which is so hard for me to get anywhere else. Like there is the bio option in supermarkets but that's the next level above 'from the farmer's', which makes that meat outrageously expensive. I also like their selection of alternative flours like buckwheat, almond, or millet. You almost can't get these anywhere else. Our family almost stopped eating gluten since Rohlík. There are so many healthier alternatives on Rohlík that I wasn't buying before. I wouldn't even know where [to buy them]..." (Ilona)

Similarly, Honza also added vegan or regional products that he "wouldn't find anywhere else or would have trouble finding somewhere else".

Online grocery shopping thus allowed the consumers to render their diets healthier and more sustainable. However, once the consumers adapted to the online shopping pattern, they started using the "My Favorites" function and the core of their shopping list became more or less the same. This finding suggests that shoppers tend to adopt new products and thus expand their usual product range together with their shopping and eating 
habits. However, once they become familiar with the online supermarket environment and start using all of its functions to their fullest potential, including the "My Favorites" function, their grocery shopping behavior seems to switch into autopilot mode. They reach efficiency in their online grocery trips by selecting mainly the products that they have ordered previously. Hence, it can be assumed that the online grocery supermarket environment leads to an initial adaptation of the typical shopping basket but when this adoption becomes fixed and shopping becomes a routine, consumers tend to stick to a similar assortment of the basket which they buy over and over again.

\section{Discussion and Conclusions}

The goal of the paper was to describe online grocery shopping behavior from the consumers' point of view. Four particular areas have been identified, which consumers see as benefits and/or pitfalls of online grocery shopping. The common factors that ran through all the accounts of online grocery shopping were time and cost efficiency, which consumers saw as the key benefits. The adverse side on efficiency, however, is the ensuing uniformity of bought groceries and subsequently the more monotonous diet of the informants.

The sought efficiency is in line with online grocery shoppers being utilitarian shoppers, as suggested by Kumar and Kashyap (2018). Hence, as utilitarian shoppers, they shop on the internet because their motivation is driven by rational decisions and efficient and deliberate actions that are related to a specific goal. Even though utilitarian shoppers display similar goal-driven behavior in the traditional brick-and-mortar store as well, the convenience of online grocery shopping makes the shopping efficiency more available through the various instruments it offers. The findings extend existing research on the time efficiency of online grocery shopping (e.g. Anesbury et al., 2015; Breugelmans et al., 2006), exploring the various instruments and techniques consumers use to save time beyond shopping on the retailer's first page. The analysis has revealed in particular that customers plan their 
online shopping trips more thoroughly than they would have planned if they were going to a physical store. They plan exactly what they are going to eat and how much of each ingredient they need. In some consumer cases, this led to the adoption and use of grocery shopping lists.

Efficiency was aided primarily by the "My Favorites" instrument that allows consumers to select the same items as in their past orders or that they have saved previously. Consumers were shown to use this instrument creatively both to control the time spent on shopping and the cost of shopping. The time saving that the "My Favorites" function creates for the customers is significant compared to the time that a consumer would have to spend to select the same products in a traditional supermarket. In this way, consumers use this function in the way described by Sorensen (2017) to eliminate choice overload and navigate the shop more efficiently. This finding then confirms what was suggested by other researchers, in that it decreases brand exploration (Pozzi, 2009). The quest for time efficiency can be added here, which also decreases new product exploration, once consumers become familiar with the online grocery supermarket environment and start using its functions to the fullest. Their buying habits then become automated, rendering the shopping monotonous.

The online supermarket customers also achieve cost efficiency through planning and the "My Favorites" instrument, which prevent them from buying unnecessary products. Hence, the overall shopping basket price decreases when compared to shopping for groceries in a traditional supermarket. This is due to the fact that consumers are not exposed to point-of-purchase marketing to such a degree. Moreover, the overall decrease in expenditure spent on groceries is also impacted by the fact that the final basket price is visible on the screen at any given moment of the shopping trip, offering more control over the spending.

The efficiency of online shopping, however, is counterweighted by the pitfall of uniform shopping, which brings monotony into people's diets. While, contrarily to some previous studies (e.g. Pozzi, 2009), at the moment of switching to online food provisioning consumers tend to explore the 
unique offer of the internet supermarket, later on they settle into a routine, considerably reducing their product and brand exploration. In terms of brand and product exploration, there thus seems to be a process that consumers go through from the first adoption of online grocery shopping to its regular use. What happens after a certain amount of time of regular online grocery shopping remains to be explored.

In conclusion, online shopping offers simple instruments that help to maximize the time and cost efficiency of the shopping trip, which are seen as the major benefits of online food provisioning. Although it has been described in previous studies that consumers use these instruments, this research has shown that they may use them in more than one way. Also, it has shown that the very efficiency offered by online grocery shopping, which is seen as the major benefit, can also represent online shopping's pitfall. By becoming more efficient in the act of food provisioning, the shopping, and consequently the consumers' diet, becomes more monotonous. As was described in the last section of the findings, shoppers seem to follow a path in which they initially alter their diet to fit the different online supermarket product offer, and then slip into a shopping routine, which allows them to shop efficiently but monotonously. This has implications for online supermarkets' logistics and marketing, in that shoppers in different stages of the process of adoption of online shopping will compose their shopping basket differently, may use the offered online instruments differently, and thus also exhibit varying sensitivity to different marketing messages.

The main limitation of the study is common to all qualitative research. It offers a deeper look at online shopping from the point of view of the shoppers themselves, but it cannot be generalized to the whole population. Future research could thus expand these findings to a representative sample. Also, as there likely seems to be an evolution of online shopping strategy in time, research that considers various stages of maturity of online shopping would shed more light on this issue. Finally, a limitation ensues from our informants using mostly one online grocery retailer. 


\section{Appendix}

\begin{tabular}{|c|c|c|c|c|c|}
\hline Respondent & Age & Occupation & $\begin{array}{l}\text { Geographic } \\
\text { location }\end{array}$ & $\begin{array}{c}\text { Family } \\
\text { structure }\end{array}$ & $\begin{array}{l}\text { Frequency } \\
\text { of online } \\
\text { grocery } \\
\text { shopping }\end{array}$ \\
\hline Adéla & 38 & $\begin{array}{l}\text { Value chain } \\
\text { manager }\end{array}$ & $\begin{array}{l}\text { Jablonec nad } \\
\text { Nisou }\end{array}$ & $\begin{array}{l}2 \text { adults }+2 \\
\text { children }\end{array}$ & Infrequent \\
\hline Barbora & 23 & $\begin{array}{l}\text { Administrative } \\
\text { assistant }\end{array}$ & Prague & 1 adult & Frequent \\
\hline Cecílie & 26 & Business analyst & Prague & 2 adults & Frequent \\
\hline Dana & 32 & $\begin{array}{l}\text { Maternity leave/ } \\
\text { hairdresser }\end{array}$ & $\begin{array}{l}\text { Březina u } \\
\text { Mnichova } \\
\text { Hradiště }\end{array}$ & $\begin{array}{l}2 \text { adults }+1 \\
\text { child }\end{array}$ & Infrequent \\
\hline Eliška & 25 & $\begin{array}{l}\text { Maternity leave/ } \\
\text { translator }\end{array}$ & Prague & 1 adult +1 child & Frequent \\
\hline Františka & 30 & Maternity leave & $\begin{array}{l}\text { Jablonec nad } \\
\text { Nisou }\end{array}$ & $\begin{array}{l}2 \text { adults }+1 \\
\text { child }\end{array}$ & Frequent \\
\hline Gabriela & 30 & Advisor & Liberec & 2 adults & Infrequent \\
\hline Honza & 27 & $\begin{array}{l}\text { Government } \\
\text { official }\end{array}$ & Prague & 1 adult & Frequent \\
\hline Ilona & 48 & Doctor & Prague & 4 adults & Frequent \\
\hline Jakub & 32 & Consultant & Prague & 1 adult & Frequent \\
\hline
\end{tabular}


A. C. Nielsen. (2015). Nielsen global e-commerce and the new retail report (April 2015).

Anesbury, Z., Nenycz-Thiel, M., Dawes, J., \& Kennedy, R. (2015). How do shoppers behave online? An observational study of online grocery shopping. Journal of Consumer Behaviour, 15(3), 261-270. doi: https://doi.org/10.1002/ cb.1566

Anic, I.-D., \& Radas, S. (2006). The relationships between shopping trip type, purchases made on promotion, and unplanned purchases for a high/ low hypermarket retailer: Evidence from the Croatian market. Economic Trends and Economic Policy, 16(107), 27-45. Retrieved from: https://hrcak. srce.hr/18362

Benn, Y., Webb, T. L., Chang, B. P., \& Reidy, J. (2015). What information do consumers consider, and how do they look for it, when shopping for groceries online? Appetite, 89, 265-273. doi: https://doi.org/10.1016/j. appet.2015.01.025

Breugelmans, E., Campo, K., \& Gijsbrechts, E. (2006). The effects of shelf display on online grocery choices. KUL Working Paper No. MO 0607. doi: http://dx.doi.org/10.2139/ssrn.944397

Childers, T. L., Carr, C. L., Peck, J., \& Carson, S. (2001). Hedonic and utilitarian motivations for online retail shopping behaviour. Journal of Retailing, 77(4), 511-535. doi: https://doi.org/10.1016/S0022-4359(01)00056-2

Chintagunta, P. K., Chu, J., \& Cebollada, J. (2009). What drives channel choice in grocery shopping? NUS Working Paper. Retrieved from: https:// www.researchgate.net/publication/242077739

Corbin, J. M., \& Strauss, A. L. (2015). Basics of qualitative research: Techniques and procedures for developing grounded theory. Los Angeles, CA: SAGE. 
Degeratu, A., Rangaswamy, A., \& Wu, J. (2000). Consumer choice behavior in online and traditional supermarkets: The effects of brand name, price, and other search attributes. International Journal of Research in Marketing, 17(1), 55-78. doi: https://doi.org/10.1016/S0167-8116(00)00005-7

GfK Czech Republic. (2017). FMCG eshopping report 2017.

Hand, C., Riley, F. D., Harris, P., Singh, J., \& Rettie, R. (2009). Online grocery shopping: Theinfluence of situational factors. European Journal of Marketing, 43(9/10), 1205-1219. doi: https://doi.org/10.1108/03090560910976447

InsightLab. (2017). Statistical data. Retrieved from: https://www.insightlab. $\mathrm{czl}$

InsightLab. (2018). Nákup potravin online 2018. Retrieved from: https:// www.insightlab.cz/nakup-potravin-online-2018/

Jiang, L., Jiang, N., \& Liu, S. (2011). Consumer perceptions of e-service convenience: An exploratory study. Procedia Environmental Sciences, 11, 406-410. doi: https://doi.org/10.1016/j.proenv.2011.12.065

KPMG. (2016). Nákupní zvyklosti v České republice 2016 (KPMG Report database). Retrieved from: https://assets.kpmg.com/content/dam/kpmg/ pdf/2016/05/KPMG-Nakupni-zvyklosti-v-CR-2016.pdf

Kumar, A., \& Kashyap, A. K. (2018). Leveraging utilitarian perspective of online shopping to motivate online shoppers. International Journal of Retail \& Distribution Management, 46(3), 247-263. doi: https:/doi.org/10.1108/ IJRDM-08-2017-0161

Mandilas, A., Karasavvoglou, A., Nikolaidis, M., \& Tsourgiannis, L. (2013). Predicting consumer's perceptions in online shopping. Procedia Technology, 8, 435-444. doi: https://doi.org/10.1016/j.protcy.2013.11.056

McCracken, G. (1988). The long interview. Newbury Park, CA: SAGE. doi: https://doi.org/10.4135/9781412986229 
Miovský, M. (2006). Kvalitativní př́stup a metody v psychologickém výzkumu. Prague: Grada Publishing.

Morgan Stanley. (2016, January 22). Are groceries the next big driver of global ecommerce? Morganstanley.com [Ideas]. Retrieved from: https:// www.morganstanley.com/ideas/online-groceries-could-be-next-bigecommerce-driver

Pozzi, A. (2009). Shopping cost and brand exploration in online grocery. NET Institute Working Paper No. 09-10. doi: https://doi.org/10.2139/ssrn.1499855

Shankar, V., Smith, A. K., \& Rangaswamy, A. (2003). Customer satisfaction and loyalty in online and offline environments. International Journal of Research in Marketing, 20(2), 153-175. doi: https://doi.org/10.1016/s01678116(03)00016-8

Sloot, L. M. (2018). Commentary: The impact of digitization on grocery retailing: Why shopping lists might be a valuable tool for brick-and-mortar grocery retailers. Journal of the Association for Consumer Research, 3(3), 410-411. doi: https://doi.org/10.1086/699390

Sorensen, H. (2017). Inside the mind of the shopper: The science of retailing. Old Tappan, NJ: Pearson.

Statista. (2015). Market value of the online grocery industry worldwide in 2015 and 2020, by country. Retrieved from: https://www.statista.com/ statistics/647443/sales-value-forecast-online-grocery-markets-worldwide/

Thompson, C. J., Locander, W. B., \& Pollio, H. R. (1989). Putting consumer experience back into consumer research: The philosophy and method of existential-phenomenology. Journal of Consumer Research, 16(2), 133-146. doi: https://doi.org/10.1086/209203

Venkatesh, V., \& Bala, H. (2008). Technology acceptance model 3 and a research agenda on interventions. Decision Sciences, 39(2), 273-315. doi: https://doi.org/10.1111/j.1540-5915.2008.00192.x 


\title{
Sažetak
}

\section{Prednosti i mane internetske kupovine namirnica iz perspektive potrošača: primjer iz Češke Republike}

\author{
ZNANSTVENI ČLANAK \\ Klára Šarkovská* \\ Zuzana Chytková**
}

Tijekom proteklog desetljeća internetska kupovina namirnica razvila se u važno područje e-trgovine te trenutno predstavlja multimilijardski biznis. lako su već provedena općenita istraživanja o različitim aspektima ponašanja kupaca prilikom online kupovine, kupovina namirnica specifična je po svojoj rutini i svakodnevnosti. Kao uobičajena i rutinska aktivnost ona utječe na svakodnevne živote potrošača, ali i na pitanja od šireg značaja, npr. problem bacanja hrane. Ovaj se rad bavi ponašanjem online kupaca i utjecajem online kupovine na njihove svakodnevne živote. Na temelju kvalitativnog istraživanja, opisuju se četiri promjene u ponašanju potrošača nakon prelaska s offline na online kupovinu namirnica. Zatim se opisuje kako te promjene utječu na svakodnevicu potrošača i na njihovu percepciju prednosti i/ili mana internetske kupovine namirnica.

Ključne riječi: online trgovina, e-trgovina, ponašanje potrošača, kvalitativno istraživanje, potrošačke prednosti, Češka Republika

JEL klasifikacija: M31, M39

* Klára Šarkovská, studentica, Odjel za marketing, Škola poslovnog upravljanja, Ekonomski fakultet u Pragu, Češka Republika, e-mail: klara.sarkovska@gmail.com.

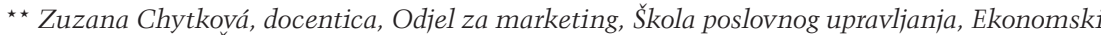
fakultet u Pragu, Češka Republika, e-mail: zuzana.chytkova@vse.cz. 